\title{
Cystatin C, kidney function and cardiovascular disease
}

\section{Arend Bökenkamp • Stefan Herget-Rosenthal • \\ Regina Bökenkamp}

Published online: 20 October 2006

(C) IPNA 2006

The online version of the original article can be found at http://dx.doi. org/10.1007/s00467-006-0192-5.

A. Bökenkamp ( $\square)$

Department of Pediatric Nephrology,

Vrije Universtiteit Medical Center,

P.O. Box 7057, 1007 Amsterdam, The Netherlands

e-mail: bokenkamp@vumc.nl

S. Herget-Rosenthal

Department of Neurology, University Hospital,

University Duisburg-Essen,

Essen, Germany

R. Bökenkamp

Department of Pediatric Cardiology,

Leiden University Medical Center,

Leiden, The Netherlands

\section{Pediatr Nephrol (2006) 21: 1223-1230}

In our review, we stated that C-reactive protein (CRP) levels were not adjusted for in the Cardiovascular Health Study. As can be seen from the legend for Table 1 of our paper, CRP was well included in the various analyses published from the Cardiovascular Health Study data.

The paper by Mitsnefes et al. [35], however, did, indeed, not correct for CRP. 